Volume 13

Issue 2 Rethinking Genocide, Mass Atrocities,

and Political Violence in Africa: New Directions,

Article 20

New Inquiries, and Global Perspectives

6-2019

\title{
Film Review: A Snake Gives Birth to a Snake
}

Juan Pablo Artinian

Torcuato Di Tella University

Follow this and additional works at: https://digitalcommons.usf.edu/gsp

\section{Recommended Citation}

Artinian, Juan Pablo (2019) "Film Review: A Snake Gives Birth to a Snake," Genocide Studies and Prevention: An International Journal: Vol. 13: Iss. 2: 168-169.

DOI:

https://doi.org/10.5038/1911-9933.13.2.1654

Available at: https://digitalcommons.usf.edu/gsp/vol13/iss2/20

This Film Review is brought to you for free and open access by the Open Access Journals at Digital Commons @ University of South Florida. It has been accepted for inclusion in Genocide Studies and Prevention: An International Journal by an authorized editor of Digital Commons @ University of South Florida. For more information, please contact digitalcommons@usf.edu. 
Film Review: A Snake Gives Birth to a Snake

\author{
Juan Pablo Artinian \\ Torcuato Di Tella University \\ Buenos Aires, Argentina
}

\begin{abstract}
A Snake Gives Birth to a Snake
Director: Michael Lessac

South Africa, USA, France, Serbia and Montenegro, Rwanda, Serbia, Ireland, Bosnia and Herzegovina, 2014
\end{abstract}

Reviewed by Juan Pablo Artinian

Torcuato Di Tella University

Documentaries on genocide and human rights violations have addressed the most paradigmatic cases of the 20th century, from the genocide against Armenians to the Jewish Holocaust, to the genocides in Cambodia and Rwanda. Moreover, different filmmakers have explored the subject from different angles: state violence, memory of survivors and denialism among other perspectives. However, Michael Lessac's 2014 documentary A snake gives Birth to a Snake from 2014 discusses a less explored topic: the relationship between the work of truth commissions (following the example of South Africa) and the ways art can help do this work of conflict resolution through a in various places where there were serious violations of human rights. The plot of the documentary revolves around the story of a South African theater company that shows its works in regions devastated by violence such as Northern Ireland, Rwanda and the former Yugoslavia. The theme of the play is reconciliation, and throughout it the actors discover that they must face the violent past of their own country and at the same time engage in a difficult dialogue between different people and their traumatic memories.

The first part of the documentary places us in South Africa itself and establishes the narrative about the process of reconciliation after Apartheid. Several referents of the political and cultural scene (both people of color and white) provide details of the South African truth commissions. The process by which different parties communicate the atrocities of the past is painful and at the same time complex. The linguistic question is fundamental in a country where different languages are spoken and different groups reside. In this way, the documentary explores the role of the various interpreters who had to listen and translate the testimonies of different people who suffered atrocities. The interpreters belong to diverse communities including both people of color and whites.

After establishing the different voices of the reconciliation process, Michael Lessac focuses on the play and its genesis. We hear about the peculiar characteristics of making a work that is performed by actors who also have had a connection with the recent traumatic experience. The director film offers images of the city of Johannesburg and the huge Soweto slum as the backdrop for the interviews to situate the narrative. We observe not only the rehearsals of the play, but also interviews to with the actors. Among the actors is the son of a former Apartheid politician.

The first place where we see the play performance is in another African country struck by violence and pain: Rwanda. The effect of seeing the dialogues of the play in a country where genocide has occurred so recently creates a powerful effect on the spectator (both of the play and the documentary). The idea of commissions of truth, reconciliation and forgiveness goes through the narrative of the play and its echoes resonate in the different rooms and regions where it is performed. The second country where the theater play is performed is Ireland. The director focuses on the challenge of mounting the play in a divided Ireland by showing images of the streets of Belfast which allude to the past of Irish armed struggle. The walls of the city still covered in the iconography of the armed organizations. The obvious contrasts are found here in a series of cleavages which evoke of the conflict between Catholics and Protestants. The discussion about political violence, the attacks of the IRA and the problem of reconciliation in the case of Northern Ireland contrast with the lines of ethnic and racial cleavages of the South African case. 
The last place where we see the performance of the play is in the former Yugoslavia. The performance of the play in the region where the systematic murder of Albanian civilians occurred -during the conflicts of the 1990s in the Balkans- is one of the most intense moments of the documentary. The dialogues between the actors and the public once again show the challenges and limits on the dissemination of ideas about the process of searching for truth, reconciliation and forgiveness. The issue of ethno-religious nationalisms in the Balkans, as well as the transition from the collapse of the Yugoslav multi-national and multi-ethnic but nationally united state to the fragmentation of the 1990s, reflects one of the most complex questions for the documentary.

From an aesthetic and formal point of view the approach of the director is successful in seeking to avoid sentimentality while at the same time evading morbid images. The documentary unfolds with a linear narrative, almost traditional, avoiding experimental explorations. On the contrary, the cumulative effect of showing the play's performance in different places shows a certain didactic angle through the idea of comparing different cases. The creation of an atmosphere where the dialogue between actors and the public prevails generates empathy in the spectator, while also of an showing the challenges associated with truth commissions as a way of resolving conflicts.

One of the problems of the documentary is the absence of a greater historical context so that the viewer can understand not only the different historical cases dealt within the documentary, but also some background of the previous history of South Africa. In that sense, it would be important to go a little deeper into the political culture and the forms of representation about Apartheid. The viewer would like to know a little more about the cultural and political scene of the country in order to understand the type of particular aesthetic created by the author of the play. On the other hand, the core of the documentary deals with the issue of memory and the representation of trauma. However, the almost prescriptive notion about the South African conflict resolution model through truth commissions eclipses the possibility of thinking comparatively about other paths of searching for truth and justice.

This last idea is perhaps one of the most complex ones to address about the documentary and refers to how each of the cases presents different stories whose cleavages seem to be simplified under the narrative of the documentary. The cleavages of ethno-nationalism in the Balkans and the ways in which they added to the problems of the post-Cold War world; the ways the wounds of the French colonial past contributed to the case of Rwanda or the discussion around the political violence and its consequences in Ireland are all included and mate to fit into the South African resolution model. Although the comparative element is interesting as an approach to explore both genocides and representations, the lack of a more complex contextualization leaves the viewer with the impossibility of thinking about conceptual differences in each case. Thus, fundamental lines of cleavage for the South African case such as the ethnic and racial question have different angles if we compare them with the case of the religious ethno-nationalism of the Balkans. The discussion on how to extrapolate models of resolution to other regions with different problems opens questions about other parts of the world and the problem of truth and reconciliation commissions in cases such as those of the Southern Cone of Latin America. The documentary, an intense and aesthetically valuable contribution, opens up questions not only about the resolution of conflicts, but also about the transmission of trauma and memory in different historical cases.

Title of the Film: A Snake Gives Birth to a Snake; Director: Michael Lessac; Producers: Jacqueline Bertrand Lessac, Michael Lessac, Emma Tammi; Cinematography: Henry Jacobson, Anastas N. Michos; Film Editor: Joel Plotch; Countries: South Africa, USA, France, Serbia and Montenegro, Rwanda, Serbia, Ireland, Bosnia and Herzegovina; Language: English; Year of Production: 2014; Production Company: Global Arts Corps; Duration: 99 minutes. 